\title{
ASSESSMENT OF QUALITY OF BLOOD BANK SERVICES PROVIDED BY HEALTHCARE WORKERS AT UNIVERSITY HOSPITALS
}

\author{
By \\ Abdel-Hamid MA., Gamal El-Din DA., El-Gaafary MM., Gabal MS. \\ Community, Environmental \& Occupational medicine. Faculty of Medicine, \\ Ain-Shams University, Cairo, Egypt
}

\begin{abstract}
:
Background: Blood transfusion services must be based on a national blood policy, including relevant legislation and regulations, which in turn must be an integral part of any national health policy. Objective: to assess the quality of services provided by healthcare workers in blood banks compared to national Egyptian standards. Material and Methods: Six hundred blood donation processes performed at the main blood banks of Eldmerdash and Elhussein university hospitals were observed using a structured checklist. Five percent of available registers were also assessed. Results: There was a blood donor questionnaire in Eldmerdash but not in Elhussein blood bank. Healthcare Workers in Eldmerdash blood bank were more adherent to quality standards concerning eligibility criteria of the donor. Healthcare workers in Eldmerdash performed medical examination and vital data measurement more frequently. Lymph node and skin examination, and routine pre-donation hemoglobin measurement were missed in both blood banks. Donors were not adequately informed about post blood donation instructions in Elhussein blood bank. No proper hand washing was done before donation and before or after clinical examination in both blood banks. There were limited resources for infection control in Elhussein compared to Eldmerdash blood bank. Basin, soap and antiseptics were not available in Elhussein blood bank. Conclusion: Quality standards concerning blood donation in Eldmerdash and Elhussein blood banks were partially fulfilled. However those standards were more fulfilled in Eldmerdash than Elhussein.
\end{abstract}

Keywords: Quality standards, Blood donation, Blood banks, Healthcare workers, University hospitals. 


\section{Introduction}

Transfusion of blood and blood products is an essential part of health care for patients deficient in one or more blood components. Therefore, organization of blood transfusion services must be based on a national blood policy, including relevant legislation, rules and regulations, which in turn must be an integral part of any national health policy (Goodman et al., 2003).

Blood banks have the unique responsibility to act as intermediary between the health donor who provides the blood and the patient who needs blood or one or more of its components. Their responsibilities include taking care of the donor before and after donation, making the gift (the blood and components) available promptly and with a guarantee of quality and safety, and monitoring that appropriately (CDC, 2004).

In Egypt, in new Kasr ElAini hospital, it was estimated that the number of donors are 100/week, the number of outpatients in need of blood are 20/week, the number of platelet aphresis is $5 /$ week and the number of plasmapheresis is 6-10/month (Blood bank of New Kasr ElAini teaching hospital, 2010).

Safe blood donors are the cornerstone of a safe and adequate supply of blood and blood products. WHO advocates and recommends to its Member States to develop national blood transfusion services based on voluntary non-renumerated regular blood donation in accordance with world health assembly resolution, which was adopted in 1975 (WHO, 2010).

Weaknesses may arise from the inability of governments to enforce laws, regulations, and/or norms. They also may come from staff who are not aware or are unable to follow quality assurance and/ or good manufacturing practices. Other problems may develop from untrained health personnel who may not follow known standards of medical practice for prescribing blood or blood products. The lack of altruistic repeat blood donors who have been shown to be healthier than replacement donors and more appropriate than paid donors as source of safe blood is also a contributing factor (Schreiber et al., 1996; Dodd et al., 2002; Cruz and Perez Rosales, 2003).

There are many definitions and perception of quality in healthcare. The simplest and perhaps the most comprehensive definition is that used by advocates of total quality management (TQM) "doing the right things right the first time and every time" (Brown, 2001). 
Quality assurance functions are assuming increased importance of the hospital transfusion service for medical, economic and regulatory reasons (AuBuchon, 1997).

The effective implementation and monitoring of such quality programs and functions involve other medical services and other HCWs (the nursing staff) throughout the hospital, such quality programs depend on the level of involvement of the transfusion medicine physician, who understands these issues and takes an active role at the hospital level (Domen,1997).

It is estimated that death from errors attributable to the transfusion process are many times more likely than death from transfusion-transmitted viral infections (Williamson et al., 1999). Therefore, assessment and monitoring of quality of blood transfusion services which are a sensitive and important issue is mandatory to provide better quality of health care.

\section{Aim of Work}

The aim of the present study is to assess the quality of blood bank services provided by healthcare workers ( $\mathrm{HCWs}$ ) at university hospitals compared to National Egyptian Standards.

\section{Material and Methods}

A cross-sectional descriptive study was conducted in Ain-Shams (Eldmerdash) and Al-Azhar (Elhussein) University hospital main blood banks. These blood banks were chosen conveniently as two representatives of health care university services. According to previous records of those blood banks, $10 \%$ of the expected blood donation processes during the 3 months of the field work (June till August 2010) were observed using a checklist (300 out of 3000 blood donation processes in each hospital). In addition, 5\% of the registers of year 2009 of blood donations were revised.

Data were collected using 2 checklists (for blood donation process and for documentation).

The blood donation checklist was used to survey the performance of HCWs during the blood donation process and infection control measures adopted. It included information about blood donor questionnaire, preliminary data, medical examination, blood donation process and infection control quality standards.

Documentation checklist included presence or absence of documentation concerning donor information, patient information, and blood donation process information. 
Blood Banks were visited randomly on the base of 3 days per week for a period of 3 months from June till August 2010 according to a preset schedule to complete observational checklists for blood donation processes.

The field visits were performed at different times of these months, at morning, afternoon and evening to asses if HCWs applied quality standards at particular time for example at morning or afternoon, due to presence of Head manager or presence of punishments or time factor had no influence on application of such quality standards.

Data collected was revised and validated and then introduced and analyzed by SPSS package version 15 .

Research conduction approval was obtained by Ain -Shams University \& ALAzhar University Ethical Committee before the start of work. An approved informed consent was obtained from the donor.

\section{Results}

\section{Quality Standards in Blood Banks:}

Blood donor questionnaires were available in El Demerdash blood bank, which was completed in $90 \%$ of the observed blood donors, but it was signed by the doctor and the donor in only $76 \%$ of the blood donation processes observed. No blood donor questionnaire was completed in Elhussein blood bank.

Regarding eligibility criteria of the donor before blood donation, table 1 shows that both blood banks (Eldmerdash and Elhussein) applied quality standards for inquiring about the appropriate age of the donor and the last blood donation in all observations (100\%). HCW asked about the timing of last meal in $72.3 \%$ and $72.8 \%$ of observations at Eldmerdash and Elhussein blood banks respectively.

Current job was ascertained in $95 \%$ of Eldmerdash blood donors compared to only $70 \%$ in Elhussein and the difference was statistically significant $(\mathrm{p}<0.01)$. However, current job was checked from the ID card of the donor, and specific occupational exposures that could carry some harm to the blood recipient were not actually considered.

Pre-donation physical exercise was not asked in both blood banks. Assigning a serial number for blood donor was done in all observed blood donation processes in both blood banks.

Eligibility criteria of females regarding pregnancy, lactation and menstruation checked in all observations at Eldmerdash blood bank. On the other hand, at Elhussein 
blood bank, pregnancy was not checked at all, lactation was checked in $28.6 \%$ and menstruation was checked in $89.8 \%$ of the observed blood donation processes (Table 1).

Information regarding history of chronic diseases, infectious diseases, blood diseases, vaccination, drugs and surgical history were found to be significantly better gathered in Eldmerdash than Elhussein blood banks $(\mathrm{p}<0.05)($ Table 1$)$.

Regarding measurement of vital data, table 2 shows that blood pressure was measured in all blood donation observations (100\%) at Eldemerdash and in $82 \%$ of observations at Elhussein Blood bank and the difference was statistically significant between both blood banks $(p<0.01)$.

As regard pulse measurement, it was measured in $89.7 \%$ of blood donation observations at Eldmerdash and in $40.1 \%$ at Elhussein blood bank. The difference was statistically significant $(\mathrm{p}<0.01)$.

Body temperature was measured in only $63 \%$ of blood donors at Eldmerdash, while it was not assessed at all at Elhussein blood bank. Body weight was nearly measured for all blood donors in Eldmerdash (99\%), while it was not measured at all in Elhussein. The difference was statistically significant between both blood banks $(\mathrm{p}<0.01)$ (Table 2).
Pre-donation assessment of hemoglobin was done in $10 \%$ of all observations in $\mathrm{El}$ Demerdash blood donors compared to $7 \%$ in Elhussein blood donors. The difference was not statistically significant $(\mathrm{p}>0.05)$. It should be noted that Hemoglobin was mainly assessed for females and suspected anemic males only in Eldmerdash. In Elhussein it was performed for suspected anemic females only (Table 2).

As regard examining the skin before donation for inspection of rash, injection scars and jaundice; table 3 shows that it was more frequently performed in Eldmerdash compared to Elhussein and there was a statistical significant difference between both blood banks. However, lymph node examination was almost not performed in both blood banks.

Blood donation process, post donation care and infection control measures

Table 3 shows that skin was disinfected by alcohol in $70 \%$ in all observations at Eldmerdash. However, it was almost not performed in Elhussein blood bank. Instead health care workers used Betadine for skin disinfection. Skin was cleaned from inside to outside with an area of $10 \times 10$ $\mathrm{cm}$ in both blood banks. Skin was left to dry completely in both blood banks. Both blood banks' HCWs left skin of the donor 
to dry before insertion of the needle into the vein in all observations by nearly $100 \%$.

Table 3 shows that $\mathrm{HCW}$ in both blood banks did not inspect the blood bag for change in color or for leakage. This may be explained by the lack of knowledge or lack of training regarding these points. Inspecting blood bags may reveal a fatal error that would cost a blood recipient his life.

There was no clamp inserted before the end of needle as it was built-in inside the agitator. However, HCWs in both blood banks inserted needle properly and fixed it with plaster and asked the donor to close and open his fist.

In $85 \%$ of the observations at Eldmerdash blood bank, agitator was used, while in Elhussein blood bank, blood was mixed with anticoagulant using agitator in all observations.

Monitoring the weight of the filled blood bag was only performed in Eldmerdash. It was not performed in Elhussein blood bank. Post transfusion care of the wound was applied in both blood banks (relief of the tourniquet and pressure applied on the needle site).

In Elhussein blood bank, only one vacutainer was filled for serology testing, while in Eldmerdash, one more vacutainer for $\mathrm{CBC}$ was filled.

Safety needle disposal was performed in both blood banks in all observed blood donation processes. Blood bag line was sealed at different sites frequently the same in both blood banks.

Table 4 shows that both Eldmerdash and Elhussein blood banks did not apply quality standards as regard giving donors rest for 20 minutes. However, HCWs in both blood banks gave donors fluids or snacks. Donors were also allowed to lie down with their legs raised up and their heads down if they felt dizzy in both blood banks.

As regard instructions given to donors post donation; table 4 shows that drinking fluids frequently, avoiding vigorous work, smoking and exposure to sunlight were advised to $10.3 \%, 16 \%, 9 \%$ and $17.7 \%$ of blood donors respectively in Eldmerdash, while in Elhussein, none of the blood donors was advised regarding such instructions and the difference was statistically significant $(\mathrm{P}<0.01)$.

Regarding quality standards applied concerning infection control measures; table 5 shows that HCWs in Eldmerdash blood bank performed hand washing after cleaning blood drop in $40.7 \%$ of 
observations compared to Elhussein blood bank in which there was no hand washing and the difference was statistically significant $(\mathrm{P}<0.05)$. HCWs in both blood banks neither perform hand washing before the donation process, nor before or after clinical examination. Also there was no hand washing performed after removal of gloves.

There was a basin, soap and antiseptic in $100 \%$ of observations in Eldmerdash blood bank compared to Elhussein blood bank in which these items were not available $(0 \%)$.

HCWs in Eldmerdash were wearing hand gloves before blood donation in $75.3 \%$ of observations compared to Elhussein blood bank health workers who were wearing gloves before donation in only $34.1 \%$ of all observations. The difference was statistically significant $(\mathrm{p}<0.01)$. In both blood banks, HCWs did not wear hand gloves before clinical examination and gloves were not changed between donors. The working surface, when dealing with blood separation, was cleaned before working in only 3 observations in Eldmerdash blood bank while it was not cleaned at all in Elhussein blood bank. HCWs in Eldmerdash blood bank removed blood drop by using a suitable disinfectant in $97 \%$ of observations compared to $46.7 \%$ in Elhussein blood banks. The difference was statistically significant $(\mathrm{p}<0.05)$.

In both blood banks, HCWs did not remove blood drop by using water, sometimes blood drop was removed by using a dry piece of cotton (2 observations in Eldmerdash and 1 observation in Elhussein blood banks) and whenever used, this piece of cotton was disposed in red infectious waste in both blood banks. HCWs in Eldmerdash blood bank did not recap needles in all observations compared to Elhussein blood bank, in which all needles were recapped after use. The difference was statistically significnat $(\mathrm{P}<$ 0.0001).

White coats were considered as one of the protective equipments for health care workers. $99.3 \%$ of HCWs in Eldmerdash blood bank were wearing white coats, compared to $89.7 \%$ in Elhussein blood bank. The difference was statistically significant $(\mathrm{p}<0.05)$.

\section{Documentation and Registration}

Five percent of 6000 registered blood donation data were assessed for completeness in both blood banks. Donor information was recorded in both blood banks in blood donation register namely donor name, donation date, blood group, 
amount of blood and type of donation, as well as serial blood bag number.

Patient information was registered all the time in Elhussein blood bank by $100 \%$ concerning patient name, hospital number, department and patient blood group, but in Eldmerdash, the frequency of documentation was less completed $(100 \%$, $98.6 \%, 97.9$ and $98.3 \%$ respectively).

Regarding handling of Blood Bag registered data, table 6 shows that the time of donation was fully recorded in all surveyed registries in Elhussein, while it was registered in only $88.7 \%$ in Eldmerdash blood bank.

All surveyed documents in Elhussein blood bank were signed by the person responsible for delivering blood bags to the patient; however, no Identification (ID) number was available. In Eldmerdash blood bank, signature was recorded in $82 \%$ of the revised documents, while the ID number was present in $70 \%$ of the observed documents. Name of person donating blood was registered in all surveyed documents in Elhussein and in only $87.3 \%$ of the revised documents in Eldmerdash. 
Table (1): Quality standards applied regarding eligibility criteria and medical history of the donor before blood donation

\begin{tabular}{|c|c|c|c|c|}
\hline Inquiry about & $\begin{array}{c}\text { Eldmerdash } \\
\mathbf{N}(\%)\end{array}$ & $\begin{array}{c}\text { Elhussein } \\
\mathbf{N}(\%)\end{array}$ & $\chi^{2}$ & P value \\
\hline Appropriate age & $300(100.0)$ & $302(100.0)$ & NA & - \\
\hline Last blood donation & $300(100.0)$ & $302(100.0)$ & NA & - \\
\hline Last meal & $217(72.3)$ & $220(72.8)$ & 0.02 & $>0.05$ \\
\hline Current Job & $286(95.3)$ & $211(69.9)$ & 67.8 & $<0.01$ \\
\hline Pre-donation Physical Exercise & $0(0.0)$ & $0(0.0)$ & $*$ & $>0.05$ \\
\hline Serial Number assignment & $300(100.0)$ & $302(100.0)$ & NA & - \\
\hline Pregnancy & $50(100.0)$ & $0(0.0)$ & 99.0 & $<0.01$ \\
\hline Lactation & $50(100.0)$ & $14(28.6)$ & 55.3 & $<0.01$ \\
\hline Menstruation & $50(100.0)$ & $44(89.8)$ & $*$ & $<0.05$ \\
\hline AIDS & $300(100.0)$ & $0(0.0)$ & 602 & $<0.01$ \\
\hline Hepatitis & $300(100.0)$ & $77(25.5)$ & 356.9 & $<0.01$ \\
\hline Malaria & $300(100.0)$ & $0(0.0)$ & 602 & $<0.01$ \\
\hline Cardiac diseases & $300(100.0)$ & $30(9.9)$ & 492.9 & $<0.01$ \\
\hline Epilepsy & $300(100.0)$ & $13(4.3)$ & 552.2 & $<0.01$ \\
\hline Neurological diseases & $300(100.0)$ & $1(0.3)$ & 598 & $<0.01$ \\
\hline Hypertension & $300(100.0)$ & $5(1.7)$ & 582 & $<0.01$ \\
\hline Cancer & $300(100.0)$ & $274(90.7)$ & 29.17 & $<0.01$ \\
\hline Liver disease & $300(100.0)$ & $1(0.3)$ & 598 & $<0.01$ \\
\hline Renal disease & $300(100.0)$ & $8(2.6)$ & 570.8 & $<0.01$ \\
\hline Diabetes Mellitus & $300(100.0)$ & $0(0.0)$ & 602 & $<0.01$ \\
\hline Recent Vaccination & $300(100.0)$ & $0(0.0)$ & 602 & $<0.01$ \\
\hline Travel from malaria area & 299(99.7) & $0(0.0)$ & 598 & $<0.01$ \\
\hline Drugs & 299(99.7) & $284(94.0)$ & 15.6 & $<0.01$ \\
\hline Blood Disease & 299(99.7) & $4(1.3)$ & 582.2 & $<0.01$ \\
\hline Surgical History & 299(99.7) & $258(85.4)$ & 44.10 & $<0.01$ \\
\hline
\end{tabular}

* Fisher Exact test 
Abdel-Hamid MA. et al.,

Table (2): Quality standards applied regarding vital data, hemoglobin, weight measurement and medical examination of skin and lymph node

\begin{tabular}{|l|c|c|c|c|}
\hline Assessment & $\begin{array}{c}\text { Eldmerdash } \\
\text { N (\%) }\end{array}$ & $\begin{array}{c}\text { Elhussein } \\
\mathbf{N}(\%)\end{array}$ & $\chi^{2}$ & P value \\
\hline Blood Pressure & $300(100.0)$ & $249(82.5)$ & 57.7 & $<0.01$ \\
\hline Pulse & $269(89.7)$ & $121(40.1)$ & 162.2 & $<0.01$ \\
\hline Temperature & $190(63.3)$ & $0(0.0)$ & 279.4 & $<0.01$ \\
\hline Hemoglobin & $30(10.0)$ & $22(7.3)$ & 1.4 & $>0.05$ \\
\hline Weight & $298(99.3)$ & $0(0.0)$ & 590.0 & $<0.01$ \\
\hline Skin Rash & $284(94.7)$ & $1(0.3)$ & 537.2 & $<0.01$ \\
\hline Skin Injection Scar & $284(94.7)$ & $0(0.0)$ & 541.2 & $<0.01$ \\
\hline Jaundice & $275(91.7)$ & $67(22.2)$ & 296.1 & $<0.01$ \\
\hline Lymph Node Examination & $2(0.7)$ & $0(0.0)$ & $* N S$ & $>0.05$ \\
\hline
\end{tabular}

* Fisher Exact test

N.S=Not Significant 
Table (3): Quality standards applied during and after Blood Donation process

\begin{tabular}{|c|c|c|c|c|}
\hline Parameter & $\begin{array}{l}\text { Eldmerdash } \\
\quad \mathbf{N}(\%)\end{array}$ & $\begin{array}{l}\text { Elhussein } \\
\mathbf{N}(\%)\end{array}$ & $\chi^{2}$ & P value \\
\hline Skin disinfection using Alcohol $70 \%$ & $300(100.0)$ & $1(0.3) * *$ & 598.01 & $<0.01$ \\
\hline $\begin{array}{l}\text { Skin is cleaned from inside to outside } \\
\text { with area } 10^{*} 10 \mathrm{~cm}\end{array}$ & $300(100.0)$ & $302(100.0)$ & NA & - \\
\hline Skin is left to dry after disinfection & $297(99.0)$ & $300(99.3)$ & N.S $*$ & $>0.05$ \\
\hline $\begin{array}{l}\text { Blood bag inspected for change in } \\
\text { color }\end{array}$ & $0(0.0)$ & $0(0.0)$ & NA & - \\
\hline Blood bag tested for leakage & $0(0.0)$ & $0(0.0)$ & NA & - \\
\hline Needle inserted $45^{\circ}$ & $300(100.0)$ & $302(100.0)$ & NA & - \\
\hline Clamp removed once blood visualized & $0(0.0)$ & $0(0.0)$ & NA & - \\
\hline Donor asked to close and open his fist & $300(100.0)$ & $302(100)$ & NA & - \\
\hline Needle fixed with plaster & $300(100.0)$ & $302(100)$ & NA & - \\
\hline Use of agitator & $255(85.0)$ & $302(100.0)$ & 48.96 & $<0.01$ \\
\hline $\begin{array}{l}\text { Blood bag monitored for weight by } \\
\text { weighing the bag }\end{array}$ & $300(100.0)$ & $0(0.0)$ & NA & - \\
\hline Weighing by space at both ends & $0(0.0)$ & $0(0.0)$ & NA & - \\
\hline $\begin{array}{l}\text { Tourniquet relieved after withdrawal } \\
\text { of blood }\end{array}$ & $300(100.0)$ & $302(100.0)$ & NA & - \\
\hline $\begin{array}{l}\text { Clamping of line before withdrawal } \\
\text { of needle }\end{array}$ & $0(0.0)$ & $0(0.0)$ & NA & - \\
\hline Pressure is applied on needle site & $300(100.0)$ & $302(100.0)$ & NA & - \\
\hline $\begin{array}{l}\text { Two vacutainers filled with donor } \\
\text { blood }\end{array}$ & $300(100.0)$ & $0(0.0)$ & NA & - \\
\hline Blood bag is sealed near needle end & $300(100.0)$ & $302(100)$ & NA & - \\
\hline Needle is disposed in safety box & $300(100.0)$ & $302(100.0)$ & NA & - \\
\hline $\begin{array}{l}\text { Blood in blood bag is pushed in blood } \\
\text { bag quickly }\end{array}$ & $300(100.0)$ & $302(100)$ & NA & - \\
\hline $\begin{array}{l}\text { Blood bag line is sealed at different } \\
\text { sites }\end{array}$ & $300(100.0)$ & $302(100)$ & NA & - \\
\hline
\end{tabular}

$\mathrm{NA}=$ Not Applicable.

* Fisher Exact test.

**Betadine is used instead of alcohol $70 \%$ in Elhussein BB. N.S=Not Significant. 
Abdel-Hamid MA. et al.,

Table (4): Quality standards applied during post donation care

\begin{tabular}{|c|c|c|c|c|}
\hline Parameter & $\begin{array}{c}\text { Eldmerdash } \\
\mathbf{N}(\%) \\
\end{array}$ & $\begin{array}{c}\text { Elhussein } \\
\mathbf{N}(\%) \\
\end{array}$ & $\chi^{2}$ & P value \\
\hline Donor given rest for 20 minutes & $0(0.0)$ & $0(0.0)$ & NA & - \\
\hline Donor given fluids or snack & $300(100.0)$ & $302(100.0)$ & NA & - \\
\hline Donor lies down if felt dizzy & $10(100.0)$ & $10(100.0)$ & NA & - \\
\hline \multicolumn{5}{|l|}{$\begin{array}{l}\text { Instructions given to the donor after } \\
\text { donation: }\end{array}$} \\
\hline Drink fluids & $31(10.3)$ & $0(0.0)$ & 32.9 & $<0.01$ \\
\hline $\begin{array}{l}\text { Leave plaster for next } 12 \\
\text { hours }\end{array}$ & $0(0.0)$ & $0(0.0)$ & NA & - \\
\hline If bleeding occur raise arm & $3(1.0)$ & $0(0.0)$ & $* N . S$ & $>0.05$ \\
\hline Avoid vigorous work & $48(16.0)$ & $0(0.0)$ & 52.5 & $<0.01$ \\
\hline Avoid smoking & $27(9.0)$ & $0(0.0)$ & 28.5 & $<0.01$ \\
\hline Avoid exposure to sunlight & $53(17.7)$ & $0(0.0)$ & 58.5 & $<0.01$ \\
\hline Total & $300(100)$ & $302(100)$ & & \\
\hline
\end{tabular}

NA=Not Applicable. $\quad *$ Fisher Exact test. $\quad$ N.S=Not Significant. 
Table (5): Quality standards applied as regard infection control measures

\begin{tabular}{|c|c|c|c|c|}
\hline Parameter & $\begin{array}{c}\text { Eldmerdash } \\
\text { N (\%) }\end{array}$ & $\begin{array}{l}\text { Elhussein } \\
\mathbf{N}(\%)\end{array}$ & $\chi^{2}$ & P value \\
\hline washing hands before working & $0(0.0)$ & $0(0.0)$ & NA & - \\
\hline washing hands before examination & $0(0.0)$ & $0(0.0)$ & NA & - \\
\hline washing hands after examination & $0(0.0)$ & $0(0.0)$ & NA & - \\
\hline $\begin{array}{l}\text { washing hands after removal of } \\
\text { gloves }\end{array}$ & $0(0.0)$ & $0(0.0)$ & NA & - \\
\hline $\begin{array}{l}\text { washing hand after cleaning blood } \\
\text { drop }\end{array}$ & $122(40.7)$ & $0(0.0)$ & $* 151.5$ & $<0.05$ \\
\hline Jewels removed before hand washing & $0(0.0)$ & $0(0.0)$ & NA & - \\
\hline Presence of a basin & $300(100.0)$ & $0(0.0)$ & $* 598.01$ & $<0.0001$ \\
\hline Available Soap & $300(100.0)$ & $0(0.0)$ & $* 598.01$ & $<0.0001$ \\
\hline Available Antiseptic & $300(100.0)$ & $0(0.0)$ & $* 598.01$ & $<0.0001$ \\
\hline $\begin{array}{l}\text { Wearing Hand gloves for clinical } \\
\text { examination }\end{array}$ & $0(0.0)$ & $0(0.0)$ & NA & - \\
\hline wearing Gloves before donation & $226(75.3)$ & $103(34.1)$ & $* 101.6$ & $<0.01$ \\
\hline Changing Gloves between donors & $0(0.0)$ & $0(0.0)$ & NA & - \\
\hline $\begin{array}{l}\text { Working surface cleaned before } \\
\text { working (as Lab tests/ Lying bed) }\end{array}$ & $3(1.0)$ & $0(0.0)$ & $* *$ N.S & $>0.05$ \\
\hline $\begin{array}{l}\text { Blood drop disinfected by suitable } \\
\text { disinfectant }\end{array}$ & $291(97.0)$ & $141(46.7)$ & $* 185.5$ & $<0.05$ \\
\hline Blood drop cleaned by water & $0(0.0)$ & $0(0.0)$ & NA & - \\
\hline $\begin{array}{l}\text { Blood drop removed by dry piece of } \\
\text { cotton }\end{array}$ & $2(0.7)$ & $1(0.3)$ & $* * N . S$ & $>0.05$ \\
\hline $\begin{array}{l}\text { Cotton piece disposed in red bag for } \\
\text { infectious waste }\end{array}$ & $2(100 \%)$ & $1(100 \%)$ & NA & - \\
\hline Needles not recapped & $\begin{array}{c}300 \\
(100.0 \%)\end{array}$ & $0(0.0 \%)$ & $* 598$ & $<0.05$ \\
\hline Staff wearing white coats & $298(99.3 \%)$ & $271(89.7 \%)$ & $* 24.9$ & $<0.05$ \\
\hline
\end{tabular}

$\mathrm{NA}=$ Not Applicable.

*Chi-Squared with Yates Continuity Correction.

**Fisher Exact test 
Table (6): Handling of Blood Bag registered data in Eldmerdash compared to Elhussein University Hospitals Blood Banks

\begin{tabular}{|l|c|c|c|c|}
\hline Parameter & $\begin{array}{c}\text { Eldmerdash } \\
\text { N (\%) }\end{array}$ & $\begin{array}{c}\text { Elhussein } \\
\mathbf{N}(\%)\end{array}$ & $\boldsymbol{\chi}^{\mathbf{2}}$ & P value \\
\hline Time of donation & $259(88.7)$ & $300(100.0)$ & 35.9 & $<0.01$ \\
\hline Person responsible for delivering blood bag to the patient: & $241(82.5)$ & $300(100.0)$ & 57.3 & $<0.01$ \\
\hline Signature & $207(70.9)$ & $0(0.0)$ & 327.0 & $<0.01$ \\
\hline ID (identification number) & $255(87.3)$ & $300(100.0)$ & 40.5 & $<0.01$ \\
\hline Name of person donating blood & $288(98.6)$ & $300(100.0)$ & $*$ NS & $>0.05$ \\
\hline Name of person receiving blood & $292(100.0)$ & $300(100.0)$ & & \\
\hline Total & & & \\
\hline
\end{tabular}

*Fisher Exact test. $\quad$ N.S=Not Significant.

\section{Discussion}

Pre-donation eligibility criteria

The presence of a guiding donor questionnaire in Eldmerdash may explain the higher quality of selecting blood donors in Eldmerdash than Elhussein. Surgery Encyclopedia for Blood Donation and Registry (2010) stated that a detailed health history of each prospective donor and giving them simple physical examination are very important for donor selection to ensure the safety of blood donation.
Signing any document is considered as a tool for delegating responsibility if any problem aroused, however, not all blood donor questionnaires in Eldemerdash blood bank was signed by the doctor.

HCWs in both blood banks approve the importance of asking about age and the time of the last blood donation. Hemoglobin is restored after 3 months from last blood donation in males and 4 months in females. The American Red Cross (2011a) stated that the plasma after blood donation is replaced within about 24 hours. Red blood 
cells need about 4 to 6 weeks after complete replacement. That is why at least eight weeks are required between whole blood donations.

Asking about the last meal is very important as confirmed by The American Red Cross (2011a) who stated that eating a healthy meal before donation is mandatory. In addition, fatty meals may alter the results of tests of infections done on all donors several hours after the fatty meal. Moreover, the donor must eat food rich in iron as spinach, red meat, fish and beans before donation to maintain a healthy iron level.

Occupational history can give an idea about the health status of the donor and his hemoglobin status if he is subjected to an exposure that can produce anemia like lead for example.

Pre-donation physical exercise was not ascertained totally in both blood banks. This may reflect that physical exercise was not conceived by HCWs as important item to ask about before donation in both blood banks. On the contrary, American Red Cross at Yale University (2010) recommended avoiding vigorous exercise before or after donation. In addition, Donahue (2011) stated that people doing severe physical exercise as competitive cyclist should not donate blood within 7-10 days of a competitive race, as the performance will be compromised.

Assigning a serial number for blood donor, as performed in all observed blood donation processes in both blood banks, was addressed as an important issue in the process of blood donation in both blood banks.

It is very important to include eligibility criteria of females regarding pregnancy, lactation and menstruation in the donor questionnaire as females who are pregnant, are not eligible to donate; and they must wait 6 months after giving birth (The American Red Cross, 2011 a). Elhussein blood banks did not inquire about this item. This could be attributed to the presence of printed questionnaire in Eldmerdash that was lacked in Elhussein. This questionnaire serves as a guide if any information was missed during history taking.

HCWs at Eldmerdash blood bank collected information about history of diseases, vaccination, drugs and surgery better than Elhussein blood banks. Novis et al. (2003) reported that all components of patient identification procedures were performed was $62.3 \%$ of all transfusions audited.

Blood pressure was more frequently checked in Eldemerdash blood bank. 
The American Red Cross (2011b) stated that blood pressure is a very important prerequisite for blood donation. It must be at least 80/50; also high blood pressure is acceptable as long as blood pressure is 180 (systolic) and below 100 (diastolic) at time of donation. Medications for high blood pressure do not disqualify a donor for blood donation.

Though pulse is very important in diagnosis of some diseases as anemia, arrhythmias and cardiac diseases, pulse assessment was missed in the majority of blood donation processes observed in Elhussein blood bank. In addition, body temperature measurement was not assessed at all in Elhussein blood bank though it is a good indicator for the infectious status of the donor.

Body weight was nearly measured for all blood donors in Eldmerdash, while it was not measured at all in Elhussein. The weight of the donor is an indicator of his blood volume. Hence low blood volumes may not tolerate the blood donation process (The American Red Cross, 2011c).

Novis et al. (2003) and WHO (2001) put basic eligibility criteria for donors' vital signs that should be followed. It appears that Elhussein HCWs were unaware of the importance of vital data assessment. Frequent training may improve the performance of those HCWs.
Pre-blood donation assessment of hemoglobin was performed in few cases in both blood banks. In Eldmerdash blood bank, the head manager mentioned that hemoglobin screening was used to be performed before, but at that time there was a problem with the device performing rapid hemoglobin testing so HCWs performed hemoglobin assessment for query cases only.

Blood donation process, post donation care and infection control measures.

Improved donor arm disinfection is one of the important quality standards that has been shown to be crucial in reducing the numbers of remaining bacteria on the venipuncture site of the donor (Lee et al., 2002). Results of the current study denote that HCWs were well trained regarding skin disinfection measures in both blood banks.

In both blood banks, HCWs missed the inspection of blood bags for change in color or for leakage. Inspecting blood bags may reveal a fatal error that would cost a blood recipient his life.

HCWs in both blood banks insert needles properly, fix it with plaster and ask the donor to close and open his fist. This is consistent with Surgery Encyclopedia for Blood Donation and Registry (2010) 
recommendations which stated that a tourniquet should be tightly in place on the donor's arm, a sterile needle should be inserted into a vein at 45 degrees, and the donor should be asked to open and close a fist to encourage blood to flow.

Monitoring the weight of the filled blood bag was not performed in Elhussein blood bank because blood bag balance was not available.

Regarding quality standards applied during post donation care, it was found that both Eldmerdash and Elhussein blood banks did not give the donors rest for 20 minutes after donation. Increased flow of donors could be the reason as these are two main university hospitals, which might interfere with the application of this standard. However, Rotary Blood Bank (2011) claimed that donor needs rest for 15 - 20 minutes before resuming his routine work, preferably lying down.

HCWs in both blood banks gave the donors fluids or snacks. This was consistent with Rotary Blood Bank (2011) which stated that immediately after resting for 15 - 20 minutes the donor is given some fluid to take. It may be a cup of coffee or milk or fruit juice along with a few biscuits or fruit.

In both blood banks, donors were allowed to lie down with their legs raised up and their heads down if they felt dizzy. The American Red Cross (2011b) stated that the donor if felt dizzy, it is preferable to elevate the feet until this feeling passes.

Instructions regarding drinking fluids frequently, avoiding vigorous work, smoking and exposure to sunlight were advised in less than $18 \%$ of observations in Eldmerdash blood bank while they were completely missing in Elhussein blood bank.

Increased flow of donors and high workload may interfere with giving advices in general to the donor. The American Red Cross (2011c) stated that the donor must be advised to drink plenty of fluids over the next 24-48 hours to replenish any fluids lost during donation, avoiding strenuous physical activity or heavy lifting for about 5 hours after donation.

In all observations, HCWs in both blood banks did not advice donors to leave the plaster on the wound for 12 hours. In addition, none of Eldmerdash and Elhussein blood donors received instructions about raising their arm if bleeding occurred. The American Red Cross (2011c) stated that when bleeding occurs after removing the bandage, pressure should be applied to the site with raising the arm for 3-5 minutes. If bleeding or bruising occurs under the skin, apply a cold pack to the area periodically during the first 24 hours. 
Quality standards applied concerning infection control measures; lack of hand washing is a serious problem. Hand washing should be performed before working, before examination, after examination, after removal of gloves and after cleaning of blood drops. CDC (2011) stated that there must be routine hand washing practices among blood banks health care workers. Staff should wash their hands with soap and water between contacts with different blood donors, and when gloves are used they should change gloves and cleanse their hands between contacts with different blood donors. An alcohol-based hand sanitizer may be used as an interim measure when soap and water are not available and hands are not visibly soiled. Unfortunately; hand washing was not done in all these procedures.

There was no basin, soap or antiseptic in all observations in Elhussein blood bank. This explains lack of hand washing among Elhussein blood bank HCWs.

In both blood banks, HCWs did not wear hand gloves before clinical examination and gloves were not changed between donors. Paucity of resources, lack of training, and lack of control regarding policy and procedures application are all behind this event.
Lack of training and knowledge, limited resources of disinfectants or increased workload would contribute to the lack or improper cleaning of working surfaces when dealing with blood separation. These results contradicted CDC (2011) recommendations which stated that environmental surfaces should be cleaned and disinfected according to standard facility protocols after each donor has vacated the station and before setting up for arrival of a new donor at that station.

HCWs observation revealed unrecapping of needles among Eldmerdash HCW while it was frequently observed among Elhussein blood bank HCWs. OSHA (2011) stated that recapping needles by a two-handed technique is prohibited. Employers are required to evaluate, select, and use engineering controls that reduce the likelihood of exposure by altering the manner in which a task is performed (e.g., sharps with engineered sharps injury protections or needleless systems) to eliminate or minimize exposure to contaminated sharps.

\section{Documentation and Registration}

Documentation is important for any organization and it carries a medicolegal importance when delegating responsibilities. Harvey et al. (1995) stated that ISO 9000 part 1 stressed on 
the importance of documentation and data control as one of the main activities of an organization.

Novis et al. (2003) results showed that frequencies of completion of patient identification as regard patient's name and wristband identification matched with blood request form in year 2000 was $54.1 \%$. Patient's name and identification number on blood request form compared with results of compatibility testing and with expiration dates on blood bag in year 2000 was $73 \%$.

Signature is considered as a commitment from the person delivering blood to the recipient.

Novis et al. (2003) stated that there was transfusion protocol including pretransfusion procedures as: time of donation, names of individuals to who blood was released recorded in logs. Transfusionists reviewed transfusion policies.Blood product labels were checked against physicians' written orders and physicians' transfusion orders were recorded in patients' records. Transfusionists autographed blood request forms to document proper identification.

\section{Conclusion}

Quality standards concerning blood donation in Eldmerdash and Elhussein blood banks were partially fulfilled.
However those standards were more fulfilled in Eldmerdash than Elhussein blood bank.

\section{Recommendations}

Quality standards of blood banks should be fully applied and regular surveys should be conducted to monitor and assess performance in blood banks.

\section{References}

1. American Red Cross at Yale University (2010). General Guidelines. Available online at: http:// www.yale.edu/redcross/donor.shtml (Accessed June 14, 2013)

2. American National Red Cross (2011a). Donation FAQS. Available on line at: http:// www.redcrossblood.org/donating-blood/ donation-faqs (Accessed January 3, 2011)

3. American National Red Cross (2011b). Eligibility criteria by alphabetical listing. Available on line at: http://www.redcrossblood. org/donating-blood/eligibility requirements/ eligibility -criteria-alphabetical-listing (Accessed January 3, 2011)

4. American National Red Cross (2011c). Tips for a successful donation. Available on line at: http://www.redcrossblood.org/donating-blood/ tips-successful-donation (Accessed January 3, 2011)

5. AuBuchon JP (1997). "Blood transfusion options improving outcomes and reducing costs." Arch Pathol Lab Med 121:40-7.

6. Blood bank of New Kasr ElAini teaching hospital (2010). Available on line at: http:// www.newkasrelaini.org/Blood\%20bank_eng. htm (Accessed October 20, 2010)

7. Brown JA (2001). The Healthcare Quality Handbook: A professional Resource and Study Guide. 16th Ed: Managed Care Consultants, Pasadena, CA. 
8. Centers for Disease Control and Prevention [CDC] (USA) (2004). Update West Nile virus screening of blood donations and transfusionassociated transmission: Morb, Mortal .Wkly. Rep; 53:281- 84.

9. Centers for Disease Control and Prevention [CDC] (2011). CDC H1N1 Flu Interim Infection Control Guidance on 2009 H1N1 Influenza for personnel a Blood. Available online at: http://www.cdc.gov/h1n1flu/guidance/blood_ facilities.htm (Accessed January 12, 2011)

10. Cruz JR and Perez Rosales MD (2003). "Availability, safety, and quality of blood for transfusion in the Americas" panam. J. public health 13: 103- 9 .

11. Dodd RY, Notari EP and Stramer SL (2002). "Current prevalence and incidence of infectious diseases markers and estimated window-period risk in the American Red Cross blood donor population." Transfusion 42: 975-79.

12. Domen RE (1997). "The Transfusion Service is an Integral and Important Component of the Hospital and should not be outsourced" Transfuse. Sci 18:565-73.

13. Donahue M (2011). De Anza College, Faculty Directory: Blood Donation FAQs. Available online at: http://faculty.deanza.edu/donahuemary/ BlooddonationFAQs (Accessed June 14, 2013)

14. Goodman C, Chan S, Collins P, Haught R and Chen YJ (2003). "Ensuring blood safety and availability in the US: technological advances, costs and challenges to payment - Final report." Transfusion 43(8S): 3S-46S.

15. Harvey E, Hewison C, Nevalainen DE and Lloyd HL (1995). "Maintaining Quality in Blood Banking." Blood Reviews 9:15-24.

16. Lee CK, Ho PL, Chan NK, Mak A, Hong J and Lin CK (2002). "Impact of donor arm skin disinfection on the bacterial contamination rate of platelet concentrates." Vox Sang 83(3):2048.
17. Novis DA, Miller KA, Howanitz PJ, Renner SW and Walsh MK (2003). "Audit of Transfusion Procedures in 660 Hospitals A College of American Pathologists Q-Probes Study of Patient Identification and Vital Sign Monitoring Frequencies." Transfusion 127:541- 48.

18. Occupational safety and health administration [OSHA] (2011). Blood borne pathogens. Available on line at: http://www.osha.gov/pls/ oshaweb/owadisp.show_document (Accessed January 12, 2011)

19. Rotary blood bank (2011). About voluntary blood donation. Available on line at: http:// www.rotarybloodbank.org/community/faqs. htm (Accessed January 11, 2011).

20. Schreiber GB, Busch MP, Kleinman SH and Korelitz JJ (1996). "The risk of transfusion transmitted viral infections." N. Engl. J. Med 334: 1685-90.

21. Surgery Encyclopedia for Blood Donation and Registry (2010). Blood Donation and Registry test, complications, time, infection, heart, cells, types, risk, cancer, rate, Definition, Purpose, Description, Preparation, Risks. Available on line at: http://www.surgeryencyclopedia. com/A-Ce/Blood-Donation-and-Registry.html (Accessed January 11, 2011)

22. Williamson LM, Lowe S and Love EM (1999). "Serious hazards of transfusion (SHOT) initiative: analysis of the first two annual reports." Br Med J 319:16- 9.

23. World Health Organization [WHO] (2001). Department of blood safety and clinical technology. "Global data base on blood safety. Summary report 1998-1999, Geneva: WHO.

24. World Health Organization [WHO] (2010). Voluntary blood donation. Available on line at: http://www.who.int/bloodSafety/Voluntary_ donation/en/ (Accessed October 4, 2010) 